\title{
An Assessment on Performances of Public and Private Waste Management Systems in Sri Lankan Cities
}

\author{
Udeshika Hettiarachchi ${ }^{1}$, Shanaka Kariyawasam ${ }^{2 *}$, and Chameli Senevirathne ${ }^{3}$ \\ ${ }^{1}$ Undergraduate, Department of Town and Country Planning, University of Moratuwa, Sri Lanka \\ ${ }^{2}$ Senior lecturer, Department of Town and Country Planning, University of Moratuwa, Sri Lanka \\ ${ }^{3}$ Research Scholar, Department of Town and Country Planning, University of Moratuwa, Sri Lanka
}

\begin{abstract}
Sri Lanka, being a developing country, currently undergoes high influx of population, rapid infrastructure developments and increasing urbanization. These have paved the way for the increase of solid waste generation rates in the country. However, the majority of the Sri Lankan cities have failed to manage their waste sustainably due to lack of proper management system. Assessment of the existing solid waste management system would be an important step towards developing a sustainable SWMS in the future for these cities. In this context, this study aims to investigate the performances of public and private sector waste management systems, to learn from each sector by identifying the positive and negative aspects of their performances and to identify the ways that can uplift the entire solid waste management system sustainably. The study employed both qualitative and quantitative data collection methods in the Negombo municipal council area whereas Multi-criteria analysis was incorporated as the main analysis technique. Findings revealed that, Private sector has better performance in economic and social measures than the Public sector whereas the Public sector has better performance in environmental measures. Accordingly, findings suggest that public private partnerships, performance measuring, regulating and benefit and risk sharing mechanisms should be incorporated towards the long-term sustainability of future SWMS.
\end{abstract}

\section{Introduction}

Since the waste generation is motivated by human activities [1], the countries which have high population growth rates and population densities are struggling to manage the generated waste [2]. Among them, majority of the developing countries including India and Sri Lanka have faced difficulties in managing solid waste, which has led to complex social, environmental and health concerns. Similar to majority of the countries around the world, the responsibility of managing waste is a mandate of Local Authorities (LAs) in Sri Lanka [3] . Although the budget allocation for waste management in LAs is in between $20 \%-25 \%$ from total budget [4], LAs have been failed to manage the waste in a sustainable manner. Currently, Sri Lanka is struggling to manage waste with the increase of solid waste volumes. As a result, $95 \%$ of the collected waste is disposed through open dumping, which has no control at all [5].

Failure of the public sector in efficient service delivery in waste management is a common scenario in developing and transition countries. This has resulted in serious disastrous conditions as well as social, health and environmental issues. Collapse of the Meetotamulla dumping site in Sri Lanka, and Gazhipur landfill site, East New Delhi are among famous examples. Therefore, attention was drawn towards the involvement of the private sector in municipal waste management [6]. Similarly, private sector involvement to the waste management can be observed in many cities of Sri Lanka. However, Private sector alone failed to manage solid waste sustainably as they aim to maximize the profit whereas Public sector aims to reduce the amount of waste and enhance the social wellbeing [7]. This mismatch of the intentions of public and private sectors paved the way to introduce Public-Private Partnership (PPP) in solid waste management. At present few municipal councils in Sri Lanka including Negombo Municipal Council (NMC), Colombo Municipal Council (CMC) practice PPP in waste management. Nevertheless, those waste management systems too failed to manage the waste sustainably. As an example, in Negombo municipal council area PPP in waste collection and private sector involvement in waste recycling is being practiced for years. But, only $47.13 \%$ of the generated waste is collected and $87.7 \%$ of collected waste is disposed through landfilling which has no control.

Open dumping and open burning are the two main waste disposal systems adopted in developing countries such as Sri Lanka [8]. These uncontrolled landfilling creates environmental issues [5] as well as health and social complications. As an example, collapsing of the Meetotamulla landfill site, which is one of the largest dumping sites in Sri Lanka, is a disastrous situation

\footnotetext{
*Corresponding author: shanakakss@gmail.com
} 
occurred resulting in loss of lives, loss of property and health concerns for the surrounding residents. Moreover, solid waste management is one of the main responsibilities of the local Authorities. Therefore, mismanagement of waste may result in loss of public money, which eventually creates economic issues. When considering the sustainable development declarations, one of the primary objectives, which have been recognized, is the improvement of the efficiency of the solid waste management system. Therefore, it has created a crucial need in the current context in developing a sustainable waste management system. To achieve the above-mentioned objective, developing countries need a considerable effort. The first step to have a sustainable waste management system is, assessment of the existing situation of the MWMS by using a well-structured and comprehensive performance assessment model [9].

Researches have been conducted to assess the performance of Municipal Waste management system as a whole in both developing and developed countries including Sri Lanka. Simultaneously, novel models, and frameworks were developed to assess the solid waste management system. However, limited studies have been conducted to assess the performance of private sector in waste management comparison to the public sector. Therefore, it is evident that there is a knowledge gap regarding comparative assessment of public and private sectors in waste management. Since the objectives of private and public sector are different, it is important to identify the performance of both the private and public sectors separately and comparatively as it affects the decision making process. Addressing the abovementioned research gap, this study attempts to investigate the performances of public and private sector waste management systems.

\section{Literature Review}

\subsection{Waste management}

Waste management is any activity involving the handling, treatment, and disposal of waste by aiming at effective controlling of the above-mentioned activities [10,11].

Although there are different types of waste management strategies including disposal, recycling, reuse, reduction etc, the impact of those strategies differ. Thus, waste management hierarchy (Figure 1) classified these strategies, according to their potential to minimize waste. Accordingly, disposal has the minimum potential to minimize waste and prevention has the highest potential to minimize waste.

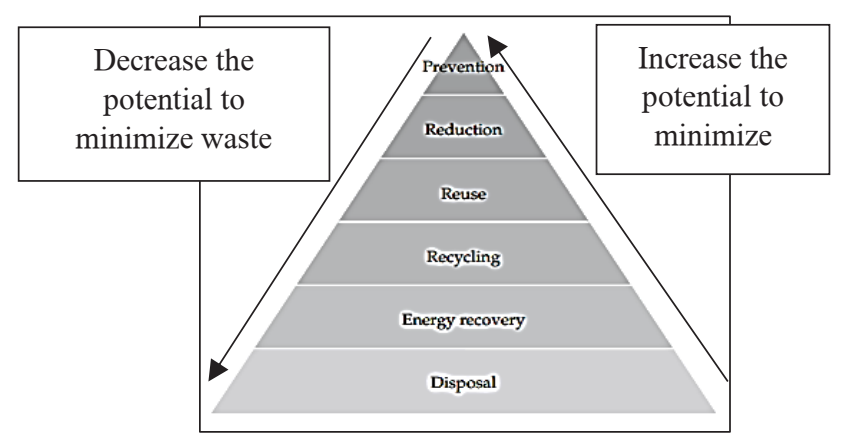

Fig. 1. Waste Management Hierarchy

Source: (Da Zhu, Asnani, Chris Zurbrugg, Sebastian Anapolsky, Shyamala Mani, 2008)

\subsection{Municipal solid waste management system}

"The entire process of storage, collection, transportation, processing and disposal of municipal solid waste by any entity engaging in such a process as a business or by any state agency, city, authority, county or any combination of thereof" can be defined as Municipal solid waste management system [10]. Municipal solid waste is "a waste type that includes predominantly household waste with some addition of commercial waste collected by a municipality within a given area [10]. The responsibility of municipal waste management has been vested for the local authorities through the Local government act in Sri Lanka [5]. Three types of operations can be identified in the municipal waste management system such as the public sector, private sector, and Public-Private Partnership (PPP). In recent years, there is an increase in using Public-Private Partnership (PPP) models for waste management [12] rather than single party operations.

\subsection{The public sector in waste management}

As per the Municipal Council Ordinance No.29 of 1947 (section No 129, 130, 131), Urban Council Ordinance No.62 of 1939 (Section No. 118,119,129), and Pradeshiya Sabha Act No15 of 1987 (section No.93, 94), the duty of conservancy and scavenging have been vested for the Municipal Council (MC), Urban Council (UC) and Pradeshiya Sabha (PS) in Sri Lanka. Accordingly, local authorities who have been mandated to manage waste can be considered as the public sector in waste management. Further, political and legal concerns, international respect to motivate the system, performing tasks vested by the ordinances and acts, use public money to provide services and regulating or contracting with the private sector can be identified as the characteristics of the public sector in waste management [13].

Institute of Global Environment Strategies (IGES) has identified some gaps in the public waste management system in Negombo. Among them most serious gaps identified are lack of labor resource and financial resources, unavailability of sufficient senior staff dedicated for solid waste management, and not having short, medium and long-term plans, goals, objectives or 
any measures to improve the solid waste management system. Moreover, poor labor management with $15 \%-20 \%$ of absenteeism, poor collaboration with the other departments who indirectly involve for solid waste management, poor relations with public, and high solid waste management expenditure were identified [14]. Also it is evident that the majority of these gaps in the Public waste management system are due to the financial constraints, technical gaps, and poor organization.

\subsection{The private sector in waste management}

The limitations of the public sector waste management system has created opportunities for the private sector to be involved. The private sector in waste management can be defined as the cooperation, institution, firm, individuals, family or community enterprises, who engage with waste management related activities [13]. They should have accounts and financial management that are not part of the accounting system of national or local government [15]. Although there can be both formal and informal private sector operators in waste management, this study has focused only on the formal private sector which has an official business license and registration in waste management.

Although the private sector engaged in efficient and productive service delivery, few limitations can be identified. As the private sector is profit oriented, enhancing the social wellbeing is neglected. Therefore, it has created a challenging situation for recycling goals and waste reduction goals. Thus, lack of concern about the environment, less control over the system and less social security benefits are among the main identified limitations [15].

Majority of the countries have tended to use PPP in the waste management due to the negative impacts of both public and private waste management systems. PPP can be defined as "transfer and control of a good or services currently provided by the public sector, either in whole or in part, to the private sector" [16]. Since there is an ability to get the investments and required technical knowledge through PPP, there is a notable increment of PPP in waste management [12]. However, it is impossible to get the maximum advantages of PPP without competition, regular performance monitoring, and accounting [16].

\subsection{Measures to evaluate waste management systems}

Many studies [9, 17] identified various performance measures such as frequency of garbage collection, cost revenue analysis; social and environmental impacts of waste treatment technologies, waste segregation analysis, etc. to assess the performance of waste management systems. Additionally, Mendes et al. used performance indicators to evaluate the performance of waste management in municipalities with seasonal tourism activities. Further, Lohri et al. evaluated the financial sustainability of the waste management system in Ethiopia. Armijo et al. used performance indicators to develop a model to improve the waste management program in Mexico. These performance measures are measured using performance indicators. Indicators describe about the status of achievement of an activity [9].Therefore, performance indicators are the main inputs in benchmarking process where the municipalities identify their underperforming key components [9]. Accordingly, many performance indicators are developed in different countries to assess the economic productivity, financial sustainability, social wellbeing and environmental sustainability of waste management systems. Therefore, the study incorporates Criteria developed by Greene \& Tonjes [18], to narrow down the identified performance measures according to the research need.

\section{Methodology}

This research is mainly focused on the assessment of the performance of public and private sectors in waste management in Sri Lankan cities. The sustainability approach, which assesses the economic, environmental, and social aspects of a system, has been used to assess both private and public sectors in waste management. Since the success or the failure of a waste management system directly affects the economic, social, and environmental sustainability of a defined area, the performance of the waste management system has been measured using the performance measures on sustainable waste management.

\subsection{Case study selection}

Five cities, which have the highest population in Sri Lanka, were chosen as the sample for case study area selection. Colombo, Dehiwala Mount Lavinia, Moratuwa, Jaffna, and Negombo municipal council areas were among them. Based on the weighted score analysis Negombo municipal council area was selected as the case study area.

Negombo is the capital city of the Gampaha district and one of the major coastal areas in Western part of Sri Lanka. Negombo Municipal council area is the boundary of the case study area and spreads over $30.8 \mathrm{~km}^{2}$ of land. Negombo is the fifth large city in Sri Lanka in terms of the population while it records a total population of 161,484. Since more economic activities have been concentrated in the selected area, the per capita waste generation of the area is recorded as 0.9764 $\mathrm{kg} /$ person/day. The total waste generation of the area is approximately 157.67 tons/per day. The highest contribution for waste generation is from the residential sector $(64 \%)$ and the lowest contribution is from the hazardous waste sector. Out of the total waste generation in Negombo Municipal council area $45.6 \%$ of the waste is kitchen waste and $24.7 \%$ of waste are grass and wood. This implies that $70.3 \%$ of the generated waste is biodegradable waste. 


\subsection{Research methodology of RQ 01 - performance measures that can be used to assess the performance of the private and public sectors in waste management}

The sampling methods, data collection methods and analysis techniques are discussed under each research question in a way that it addresses the mentioned research gap.

Data was collected through literature review and an expert opinion survey. The sampling method of the respondents of expert opinion survey and the literature review was based on judgement sampling. The sample selection criteria of the expert opinion survey respondents were:

I. Knowledgeable about the situation of waste management in NMC.

II. Having a minimum five years of experience in the waste management field.

Whereas the Selection criteria of the literature review were:

I. It should be published within 10 years period of time

II. It should discuss about the assessment of the waste management system.

Sample size for both expert opinion survey and literature review were ten. The Performance measures identified through the literature review were validated through the expert opinion survey and then further refined through a relative important index analysis.

\subsection{Research methodology of RQ 02 - how the performances vary in between private and public waste management systems?}

Data were collected through interviews, questionnaire survey and records of the Negombo Municipal Council. The sample of the public sector respondents for the questionnaire survey and the interviews was selected through judgement sampling and the selection criteria were the experience and the knowledge about waste management in NMC. Moreover, the sample of private sector respondents was selected through snowball sampling and collected data analyzed through multicriteria analysis, and Complex Stakeholder Perception Mapping (CSPM) [19].

\subsection{Research methodology of RQ 03 - recommendations to uplift the entire waste management system from the local authority perspective}

Data was collected through an expert opinion survey and the judgement sampling method was used as the sampling technique. The collected data were analyzed through thematic analysis to bring out the best recommendations that can used to uplift the waste management system sustainably.

\section{Results}

\subsection{Research question 01 - selection of the appropriate performance measures}

The performance measures that can be used to evaluate the performance of a waste management system were identified through the literature review. Since there are plenty of performance measures, the most appropriate measures were selected by using the following criteria [18]:

1. Indicator measures close to the possible result that is intended to measure

2. The indicator should be simple and easy to interpret

3. Data for the indicator is of sufficient, dependable, and consistent quality for decision making

4. The indicator provides a meaningful measurement of system change; the indicator is useful for daily decision making regarding the system.

5. The indicator is important for communicating information about systems

6. The indicator allows for program comparison

Identified performance measures through the literature were further narrowed down to seven measures based on above-mentioned six (06) criteria. Moreover, the measures, which obtained more than 0.5 for the Relative Important Index (RII), were selected for the study. The selected measure and the obtained values for the RII are shown in the Table 1.

Table 1. Selected Performance Measures and the RII Value

\begin{tabular}{|l|l|l|}
\hline Performance measure & RII & $\begin{array}{l}\text { Selected or } \\
\text { not }\end{array}$ \\
\hline Cost and revenue analysis & 0.98 & Selected \\
\hline Resource Efficiency & 0.92 & Selected \\
\hline Zero waste index & 0.74 & Selected \\
\hline Waste diversion rate & 0.48 & Not selected \\
\hline GHG emission & 0.64 & Selected \\
\hline No. of job opportunities provided & 0.64 & Selected \\
\hline Frequency of garbage collection & 0.76 & Selected \\
\hline
\end{tabular}

Further, three measures were selected from the suggestions of the respondents of the expert opinion survey and those measures were based on the number of times which the measure was suggested by the respondents. The selected measures are shown in the Table 2.

Table 2. Selected Measures from the Expert Suggestions

\begin{tabular}{|l|l|l|}
\hline No & Selected measure & $\begin{array}{l}\text { Number of } \\
\text { experts } \begin{array}{r}\text { of } \\
\text { who } \\
\text { have suggested }\end{array}\end{array}$ \\
\hline 1 & Waste segregation & 5 \\
\hline 2 & $\begin{array}{l}\text { Time take to respond to the } \\
\text { issues and complaints }\end{array}$ & 3 \\
\hline 3 & Method of waste disposal & 4 \\
\hline
\end{tabular}


Finally, nine refined measures that can be used to measure the performance of the private and public sectors in managing waste in Sri Lankan cities were selected. Measures and their categories are shown in the Table 3.

Table 3. Performance Measure Details and the Category

\begin{tabular}{|l|l|l|l|c|}
\hline Sector & \multicolumn{4}{|c|}{ Total values } \\
\cline { 2 - 5 } & Economic & $\begin{array}{c}\text { Environme } \\
\text { nt }\end{array}$ & Social & $\begin{array}{c}\text { Overall } \\
\text { sustainability }\end{array}$ \\
\hline Public & $13.08 /$ & $37.81 /$ & $18.81 /$ & $69.70 / \mathbf{1 0 0}$ \\
sector & $\mathbf{2 7 . 5 8}$ & $\mathbf{4 0 . 4 9}$ & $\mathbf{3 1 . 9 3}$ & \\
\hline Private & $27.58 /$ & $23.67 /$ & $31.93 /$ & $83.17 / \mathbf{1 0 0}$ \\
sector & $\mathbf{2 7 . 5 8}$ & $\mathbf{4 0 . 4 9}$ & $\mathbf{3 1 . 9 3}$ & \\
\hline
\end{tabular}

\subsection{Research question 02 - performance of the public and private sector in managing waste}

The multi-criteria analysis and Complex Stakeholder Perception Mapping were used to understand the overall performance of both public and private waste management systems. Results of the multi-criteria analysis shown in the Table 4.

According to the results of the Multi Criteria Analysis, it is evident that the private sector has a better overall performance compared to the public sector in terms of sustainable waste management in Negombo Municipal Council area.

Results of the complex stakeholder perception mapping also clearly shows the performance of the both sectors in managing waste as shown in the Table 5. Here performances of each sector under each measure have been visualized based on below color grading:

Not performed

Very low performance

Low performance

Medium performance

High performance
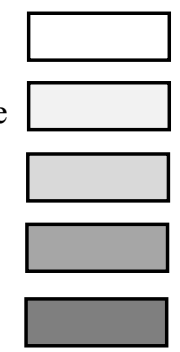

Table 4 - Results of the Multi Criteria Analysis

\begin{tabular}{|c|c|c|c|}
\hline Aspect & $\begin{array}{l}\text { Performance } \\
\text { measure }\end{array}$ & Indictor & Source \\
\hline \multirow{7}{*}{ 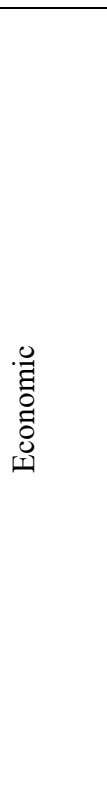 } & \multirow[t]{3}{*}{$\begin{array}{ll}\text { Cost } & \text { and } \\
\text { revenue } & \\
\text { analysis } & \end{array}$} & $\begin{array}{l}\text { Cost per ton of } \\
\text { waste collection }\end{array}$ & $\begin{array}{l}\text { Expert } \\
\text { opinion } \\
\text { survey }\end{array}$ \\
\hline & & $\begin{array}{l}\text { Revenue per ton } \\
\text { of } \quad \text { waste } \\
\text { collection }\end{array}$ & $\begin{array}{l}\text { Expert } \\
\text { opinion } \\
\text { survey }\end{array}$ \\
\hline & & $\begin{array}{l}\text { The cost-benefit } \\
\text { ratio of waste } \\
\text { recycling }\end{array}$ & $\begin{array}{l}\text { Expert } \\
\text { opinion } \\
\text { survey }\end{array}$ \\
\hline & \multirow[t]{4}{*}{$\begin{array}{l}\text { Resource } \\
\text { efficiency }\end{array}$} & $\begin{array}{l}\text { Amount of waste } \\
\text { collected by } \\
\text { labor within one } \\
\mathrm{km}^{2}\end{array}$ & $\begin{array}{l}\text { Expert } \\
\text { opinion } \\
\text { survey }\end{array}$ \\
\hline & & $\begin{array}{l}\text { Amount of waste } \\
\text { supervised by } \\
\text { one supervisor }\end{array}$ & $\begin{array}{l}\text { Expert } \\
\text { opinion } \\
\text { survey }\end{array}$ \\
\hline & & $\begin{array}{l}\text { Number of waste } \\
\text { ton collected by } \\
\text { one fuel L }\end{array}$ & $\begin{array}{l}\text { Expert } \\
\text { opinion } \\
\text { survey }\end{array}$ \\
\hline & & $\begin{array}{l}\text { Amount of waste } \\
\text { collected by one } \\
\text { tractor }\end{array}$ & $\begin{array}{l}\text { Expert } \\
\text { opinion } \\
\text { survey }\end{array}$ \\
\hline \multirow{4}{*}{ 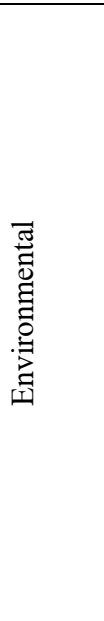 } & $\begin{array}{l}\text { Zero waste } \\
\text { Index }\end{array}$ & Zero waste index & $\begin{array}{l}\text { (Lehmann } \\
\& \text { Zaman, } \\
\text { 2014) }\end{array}$ \\
\hline & GHG emission & $\begin{array}{l}\text { GHG emission } \\
\text { per month from } \\
\text { waste } \\
\text { management } \\
\text { activities }\end{array}$ & $\begin{array}{l}\text { (Kumar \& } \\
\text { Sharma, } \\
\text { 2013) }\end{array}$ \\
\hline & $\begin{array}{l}\text { Waste } \\
\text { segregation } \\
\text { analysis }\end{array}$ & $\begin{array}{l}\text { Percentage of } \\
\text { collected as } \\
\text { segregated waste }\end{array}$ & $\begin{array}{l}\text { Expert } \\
\text { opinion } \\
\text { survey }\end{array}$ \\
\hline & $\begin{array}{l}\text { Waste } \\
\text { disposal } \\
\text { method }\end{array}$ & $\begin{array}{l}\text { Amount of waste } \\
\text { disposed through } \\
\text { different disposal } \\
\text { method from the } \\
\text { total waste } \\
\text { collection }\end{array}$ & $\begin{array}{l}\text { Expert } \\
\text { opinion } \\
\text { survey }\end{array}$ \\
\hline \multirow{3}{*}{$\begin{array}{l}\bar{\pi} \\
\frac{\pi}{0} \\
0 \\
\mathscr{n}\end{array}$} & $\begin{array}{l}\text { Frequency of } \\
\text { garbage } \\
\text { collection }\end{array}$ & $\begin{array}{l}\begin{array}{l}\text { Number of days } \\
\text { of } \\
\text { collection } \\
\text { week }\end{array} \\
\end{array}$ & $\begin{array}{l}\text { (Hajar, et } \\
\text { al., 2020) }\end{array}$ \\
\hline & $\begin{array}{l}\text { Number of job } \\
\text { opportunities } \\
\text { provided }\end{array}$ & $\begin{array}{l}\text { Number of job } \\
\text { opportunities } \\
\text { provided per } \mathrm{km}^{2}\end{array}$ & $\begin{array}{l}\text { (Hajar, et } \\
\text { al., 2020) }\end{array}$ \\
\hline & $\begin{array}{l}\text { Response to } \\
\text { complaints } \\
\text { and issues } \\
\text { solving } \\
\text { capacity }\end{array}$ & $\begin{array}{l}\text { Minimum } \\
\text { number of days } \\
\text { take for } \\
\text { responding }\end{array}$ & $\begin{array}{l}\text { Expert } \\
\text { opinion } \\
\text { survey }\end{array}$ \\
\hline
\end{tabular}


Table 5. Results of the CSPM

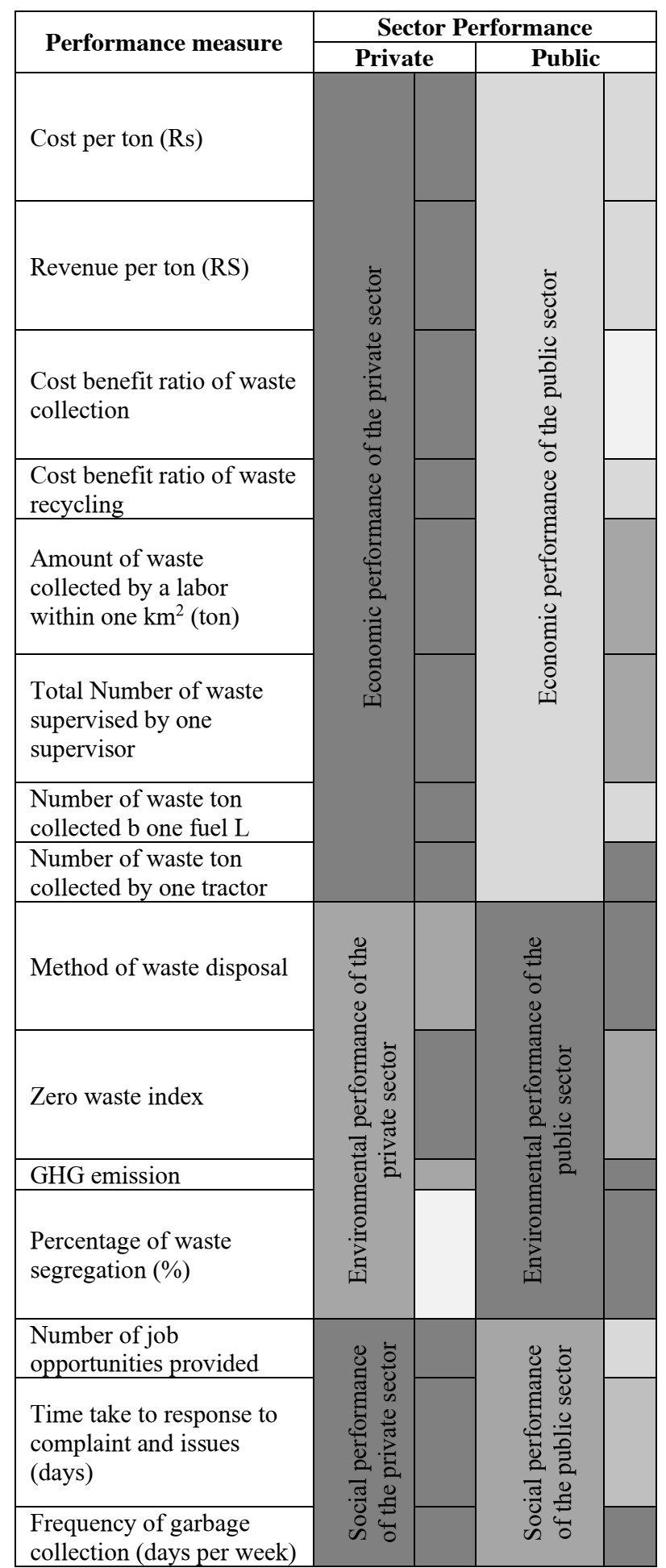

As the above-mentioned Table shows, the private sector has a better performance in social and economic arenas than the public sector. However, public sector has better performance in the environmental category. Hence, when considering all three categories of performance indicators private sector has a better performance than the public sector in Negombo Municipal Council area.

\section{Conclusions and recommendations}

The study has focused on the evaluation of the performances of both public and private sectors in waste management. It has identified that, cost-benefit analysis, resource efficiency, method of waste disposal, Zero waste index, GHG emission, Percentage of waste segregation, Number of job opportunities provided, time take to response to complaints and issues, frequency of garbage collection are the most suitable measures to assess the sustainable waste management performances of both public and private sectors in Sri Lanka. Moreover, results depict that the private sector has the overall best performance in managing waste in Sri Lankan cities whereas the Public sectors has best performance in environmental category while the private sector has the best performance in social and economic arenas.

Economic performance of the Private sector (27.57\%) is almost double the performance of the public sector (13\%). Further, high cost and resource efficiency of the private sector is caused due to the profit maximization intension of the private. In contrast lower cost efficiency and resource efficiency of the public sector is due to not having regular performance measures, political influence, comparatively low competition, and lack of the expertise technology. The below expert opinions confirms the above point.

"When considering the limitations in private sector by nature private sector will have a profit maximizing intention. So they give more priority to reaction time, and resource efficiency than environmental and social concerns" (NGO officer with 35 years of experience on waste management)

"In the public sector the limitation of low cost effectiveness and efficiency is due to lack of performance measuring systems in the public sector" (Municipal Council official with 05 years of experience on waste management)

When considering the environmental performance, public sector reflects the best performance. However, a drastic difference between the performances of both sectors cannot be seen. Although having more recycling centers have positively affected to increase the performance of private sector, analysis shows that the private sector has a limited intention towards the waste segregation in the selected case study area.

"In Sri Lanka, most of the private sector companies who engaged in SWM activities do the contractors role of collection and disposal of waste in a particular local authority area, based on a contact agreement. These agreements are limited in scope and do not provide resources for waste management, rather waste dumping or disposal only. Therefore the above limitations are prevailing" (NGO officer with 24 years of experience on waste management)

Although the public sector has a good performance in environment category, it is a relatively low level score compared to category maximum score (37.80\%). It is due to not having strategic plans to manage as well as lack of technical knowledge and expertise for recycling. The below quote extracted from the expert opinion survey proves it:

"In the government sector operation in SWM is still evolving over the past 30 to 40 years. But still do not 
follow a comprehensive planning approach to SWM. They usually adopt firefighting approach in addressing SWM issues...They do not formulate strategic plans for managing their waste and do engage in aged old collection and dumping practices..." (NGO officer with 24 years of experience on waste management)

Considering the social performance of the both sectors, private sector has better performance than the public sector because of the less time taken to respond for the issues and complaints, and the ability to generate more job opportunities through recycling centers,. Hence, it can be concluded that as a whole, private sector has the better performance level than the public sector in waste management within the Sri Lankan context. However their operations should be regulated through better regulations and contractual agreements. Loopholes in the law enforcement, regulations, and agreements have provided private sectors operators a huge freedom. This has motivated them towards profit maximization only.

\subsection{Recommendations}

According to the opinions of experts in the waste management field, few recommendations to uplift the municipal waste management system can be identified. Mainly, practicing public private partnership with a strong monitoring and regulating mechanism can be suggested. As the analysis depicts some of the limitations of public sector have been successfully addressed by the private sector whereas the limitations of the private sector have been addressed by the public sector. Therefore, there is a possibility to uplift the municipal waste management systems to harness each party's potentials and minimize limitations. Further, this has been proved by the expert ideas mentioned below.

"What should be taken into consideration is that how well the two parties operate in corporation to bring overall benefit to the community/ society they operate. If the overall benefit is higher, private sector can operate with a profit motive in a particular section while government ensuring social and environmental protection through law and order, and in the same section there could be elements that are not so profitable to operate. Then the government can operate the required services in those elements using part of the revenue recovered as tax and charges" (NGO officer with 35 years of experience on waste management)

According to the findings of the study, formulation of regulations to minimize the asymmetry of information, implementation of performance measurement system to evaluate resource efficiency and effectiveness, conducting awareness programs and capacity building programs, incentivize the public employee and introduce benefit sharing, risk/cost sharing, and emphasize social responsibilities and long term sustainability concepts in to private sector can be suggested as few other recommendations. Below expert opinions prove the findings of the study and further recommend LAs to develop strategic plans while strictly monitoring the process. Finally, these recommendations can be incorporated when developing sustainable waste management systems in the future.

"Introduction of benefit sharing, risk/cost sharing and corporate social responsibility schemes into private sector" (An academic with 12 years of experience on waste management)

"The Government and LAs must develop a master plan for each LA area and develop contract agreements to implement part/s of that master plan by the private sector partners. Their operations should be strictly monitored and guided to achieve the set targets. The LAs must play a facilitator role to get the maximum benefits from private sector engagement for public betterment and sustainability." (NGO officer with 24 years of experience on waste management)

"Government should bring in practical and implementable regulations in directing private sector to consider people and planet in their operations, these could be through tax benefits, penalties etc. which will make their business less profitable or shutdown if they are not serious about people and environment."(NGO officer with 35 years of experience on waste management)

The study gives a strong output that should be considered by urban planners' in developing strategic plans for the sustainable waste management systems in a country. Moreover, the study was limited to the expert ideas without incorporating the public participation due to the pandemic outbreak during the data collection. Finally, future studies can explore the satisfaction level and the perception of the residents regarding public private partnerships and further assess the performance by incorporating the perception of people, which is an important aspect in performance assessment.

This research was funded by the University of Moratuwa Senate Research Committee Grant- SRC/ST/2020/19.

\section{References}

1. Zurbrugg, C., Urban solid waste management in low-income countries of Asia how to cope with the garbage crisis. Presented for: Scientific Committee on Problems of the Environment (SCOPE) Urban Solid Waste Management Review Session, Durban, South Africa, 2002: p. 1-13.

2. $\mathrm{Vu}$, H.L., K.T.W. Ng, and D. Bolingbroke, Parameter interrelationships in a dual phase GISbased municipal solid waste collection model. Waste Management, 2018. 78: p. 258-270.

3. Vidanaarachchi, C., S. Yuen, and S. Pilapitiya, Municipal solid waste management in the Southern Province of Sri Lanka: Problems, issues and challenges. Waste management (New York, N.Y.), 2006. 26: p. 920-30.

4. Aleluia, J. and P. Ferrão, Characterization of urban waste management practices in developing Asian countries: A new analytical framework based on waste characteristics and urban dimension. Waste management, 2016. 58: p. 415-429. 
5. Bandara, N. Municipal solid waste management-The Sri Lankan case. in Conference on Developments in Forestry and Environmental Management in Sri Lanka. 2008.

6. Olukanni, D.O. and C.O. Nwafor, Public-private sector involvement in providing efficient solid waste management services in Nigeria. Recycling, 2019. 4(2): p. 19.

7. da Silva, C.L., N. Weins, and M. Potinkara, Formalizing the informal? A perspective on informal waste management in the BRICS through the lens of institutional economics. Waste Management, 2019. 99: p. 79-89.

8. Ferronato, N. and V. Torretta, Waste Mismanagement in Developing Countries: A Review of Global Issues. International Journal of Environmental Research and Public Health, 2019. 16: p. 1060.

9. Abdulaziz AlHumid, H., et al., Performance Assessment Model for Municipal Solid Waste Management Systems: Development and Implementation. Environments, 2019. 6(2): p. 19.

10. Asian Development Bank Proposed loan Republic of Uzbekistan: Solid Waste Management Improvement Project. 2013.

11. Igbinomwanhia, D.I., Status of waste management. Integrated Waste Management, 2011. 2: p. 11-34.

12. Sabolová, V., Public Private Partnership in waste management. Scientific papers of the University of Pardubice. Series D, Faculty of Economics and Administration. 14 (2009), 2009.

13. Van de Klundert, A. and I. Lardinois, Community and private (formal and informal) sector involvement in municipal solid waste management in developing countries. WASTE Consultants, Advisers on Urban Environment and Development, Nieuwehaven, 1995. 201: p. 2801.

14. Karunarathana, A., et al. State of municipal solid waste management in Negombo city, Sri Lanka. 2019.

15. Coad, A., Private sector Involvement in solid waste Management. Avoiding problems and building on successes. CWG Publication Series, 2005. 2.

16. Massoud, M.a. and M. El-Fadel, Public-private partnerships for solid waste management services. Environmental Management, 2002. 30(5): p. 06210630.

17. Rodrigues, A., et al., Developing criteria for performance assessment in municipal solid waste management. Journal of Cleaner Production, 2018. 186: p. 748-757.

18. Greene, K.L. and D.J. Tonjes, Quantitative assessments of municipal waste management systems: Using different indicators to compare and rank programs in New York State. Waste Management, 2014. 34(4): p. 825-836.
19. Kariyawasam, S., M. McGovern, and C. Wilson, Partial information and complex development decisions: Illustrations from infrastructure projects. Environmental Impact Assessment Review, 2019. 78. 